\title{
The Gut and Lung Morphometry in Experimental and Natural Lineage 1 Variant of Peste des Petits Ruminants Virus Infection in Nigerian Goats
}

\author{
Morfometría Intestinal y Pulmonar en la Infección Natural y Experimental \\ del Virus Peste des petits ruminants del linaje 1 en Cabras de Nigeria
}

Emikpe, B.O.; Taiwo, V. O. \& Onilude, O. M.

EMIKPE, B. O.; TAIWO, V. O. \& ONILUDE, O. M. The gut and lung morphometry in experimental and natural lineage 1 variant of Peste des petits ruminants virus infection in Nigerian goats. Int. J. Morphol., 29(2):585-590, 2011.

SUMMARY: The lung and gut morphometry in both natural and experimental Peste de petit ruminant (PPR) virus which are scanty in literature hence the need for this study. The goats that were submitted for necropsy in the Department of Veterinary Pathology University of Ibadan between 2009 and 2010 and the gross pathological diagnosis were PPR were enrolled in this study. The degree of pneumonia as a percentage of the total lung volume was estimated using standard methods. The gut morphometry of goats experimentally infected with PPR virus was also used. Student "T" test was used for the test of significance in evaluating the effect of age, sex and the lung consolidation pattern in natural PPR and analysis of the gut morphometry. Complicated PPR had significant higher pulmonary consolidation when compared with the uncomplicated PPR $(\mathrm{p}<0.05)$. The pulmonary consolidation was significantly higher on the right lung with a mean percentage value of 6.54 than the left lung $(\mathrm{p}<0.05)$. The caudal lobe was more consolidated than the cranial and middle lobes in natural PPR. The pulmonary consolidation was more in goats less than a year, while the buck had a significantly higher pulmonary consolidation than the does $(\mathrm{p}<0.05)$. There was no significant difference in the mean length of the villi and width of the villi of PPR virus infected goats when compared to the control, however a significant difference was observed in the cryptal depth ( $\mathrm{p}<0.05$ ). There was a significant difference in the mean villi length and cryptal depth of goats with complicated PPR (Mannheimia hemolytica) infected goats $(p<0.05)$ relative to the control. From this study, it showed that most natural PPR were complicated with bacteria and this complication may have contributed to the fatality associated with PPR especially those caused by lineage 1 viruses. This study also showed that secondary bacterial involvement in course of PPR affect the gut morphometry and that could account for the severity of intestinal lesion commonly observed with field PPR in Nigerian goats.

KEY WORDS: Morphometry; Gut; Pneumonia; Natural PPRV; Experimental PPRV; Goats.

\section{INTRODUCTION}

Goat being the first ruminant to be domesticated as they descended from the species Capra oegragus from which new varieties of breed evolved as they were influenced by the environment they found themselves (Williamson \& Payne, 1984). Goat production in Nigeria makes a major contribution to the agrarian economy as goat is considered to be one of the most important food producing animals. Goat is assuming a great importance in Nigeria as source of high quality meat in addition to milk and skin (Osuagwuh \& Akpokodje, 1981).

Despite the importance of goat production in Nigeria socially, traditionally and economically, there are two prin- cipal constraints that impede the optimal performance of this animal which are diseases and inadequate food supply. According to ILCA (1979), the most serious single cause of production losses ascribable to disease among all small ruminants in West Africa is Pestes des petits ruminant (PPR). It was first described in Cote' d'Ivore in West Africa in 1942. It was reported that the disease causes an estimated annual loss of over a million naira in Nigeria as of 1979 (Lamorde, 1980).

Pestes des petits ruminants (PPR) is an acute and highly contagious viral disease of small ruminants, which is characterized by high fever, ocular and nasal discharge, 
pneumonia, necrosis and ulceration of the mucous membrane and inflammation of the gastro-intestinal tract leading to severe diarrhea and high mortality. It affects small ruminants, especially goats, which are highly susceptible, and occasionally wild animals. Observation on field outbreak suggests that, in goat, morbidity can range between $50 \%$ and $100 \%$ while mortality can be between $20 \%$ and $100 \%$. In severe cases, whole flocks have been wiped out. Severe losses can occur in new assembled animals especially sudden death is associated with this disease causing production and financial losses to farmer. Clinically, pneumonia and diarrhea are the major features of PPR in which the animal becomes recumbent and dies.

To further understand the pathogenesis of this dreaded disease of goats, the lung and gut morphometry in both natural and experimental PPR which are scanty in literature needed to be elucidated.

\section{MATERIAL AND METHOD}

Lung morphometry. The goats that were submitted for necropsy in the Department of Veterinary Pathology University of Ibadan between 2009 and 2010 and the gross pathological diagnosis were PPR were enrolled in this study. The degree of consolidation or pneumonia as a percentage of the total lung volume, was estimated as described by Jericho \& Langford (1982) and Odugbo et al., (2004). The extent of pneumonia was determined by visual observation, palpation and measurement of the lesion which is manually plotted onto a lung diagram and then estimated as a percentage of each lobe.

Histopathology. Portions of the intestine were collected from a formalin fixed natural and previous experimental PPR and PPR and Mannheimia hemolytica infected goat samples (Emikpe \& Akpavie, 2010a; Emikpe et al., 2010). Pieces of the intestinal tissue were cut and fixed in $10 \%$ buffered formalin in a labeled bottle. Tissues were processed routinely and embedded in a paraffin wax. Sections 5 microns thick were cut and stained with haematoxylin and eosin and examined under the light microscope.

Measurement of Gut morphometry. Measurement of the gut morphometry was as described by Eyarefe et al. (2008) i.e. the length of the villi, width and cryptal depth were measured under the microscope using a graduated eyepiece in microns with a $10 \mathrm{X}$ objective lens given a magnification $\mathrm{x} 100$. Five randomly selected villi were measured in each slide per field, five fields were used and are recorded and the results were analyzed statistically.
Statistics. Student "T" test was used for the test of significance in evaluating the effect of age, sex and the lung distribution in the consolidation pattern in natural PPR and analysis of the result of the gut morphometry.

\section{RESULTS}

Pulmonary Consolidation. The lung morphometry of the goats that were diagnosed to have PPR were used. Of these, $60 \%$ were observed to have complicated PPR having higher pulmonary consolidation while the other $40 \%$ had uncomplicated PPR with lesser pulmonary consolidation as shown in Table I.

Lung Morphometry. The pulmonary consolidation is higher on the right lung with a mean percentage value of 6.54 than the left lung with a mean percentage value of 2.8 and accessory lobe with a mean percentage value of 0.16 as shown in Table II.

Lobar Distribution. The pulmonary consolidation in the caudal lobe had a mean value of 5.41 while the cranial lobe had a mean percentage value of 3.08 and the middle lobe was 0.85 as shown in Table III.

Age Influence. The pulmonary consolidation is more in goats less than a year with a mean percentage value of 5.54 and goats of 7 month old show pulmonary consolidation with a mean percentage value of 3.96 while goats of $11 / 2$ years of age show no degree of pulmonary consolidation i.e. mean value of 0 as shown in Table IV.

Sex Influence. The male has a higher pulmonary consolidation with a mean percentage value of 13.04 than the female having a mean percentage value of 6.94 as shown in Table V.

Gut histopathology. The pathological changes observed in the intestine include villous atrophy, degeneration and erosion with necrosis of the submucosa glands. There were also infiltrations of macrophages, giant cells, and numerous lymphocytes in the submucosa with depletion of the payer's patches.

Gut Morphometry. There were no significant differences in the mean length of the villi and width of the villi of PPR virus infected goats but a significant difference was observed in the cryptal depth $(\mathrm{p}<0.05)$ while a significant difference was observed in the mean villi length and cryptal depth of the complicated PPR with Mannheimia hemolytica infected goats $(\mathrm{p}<0.05)$ relative to the control as shown in Table VI. 
Table I. Percentage pulmonary consolidation in natural PPRV infection in goats.

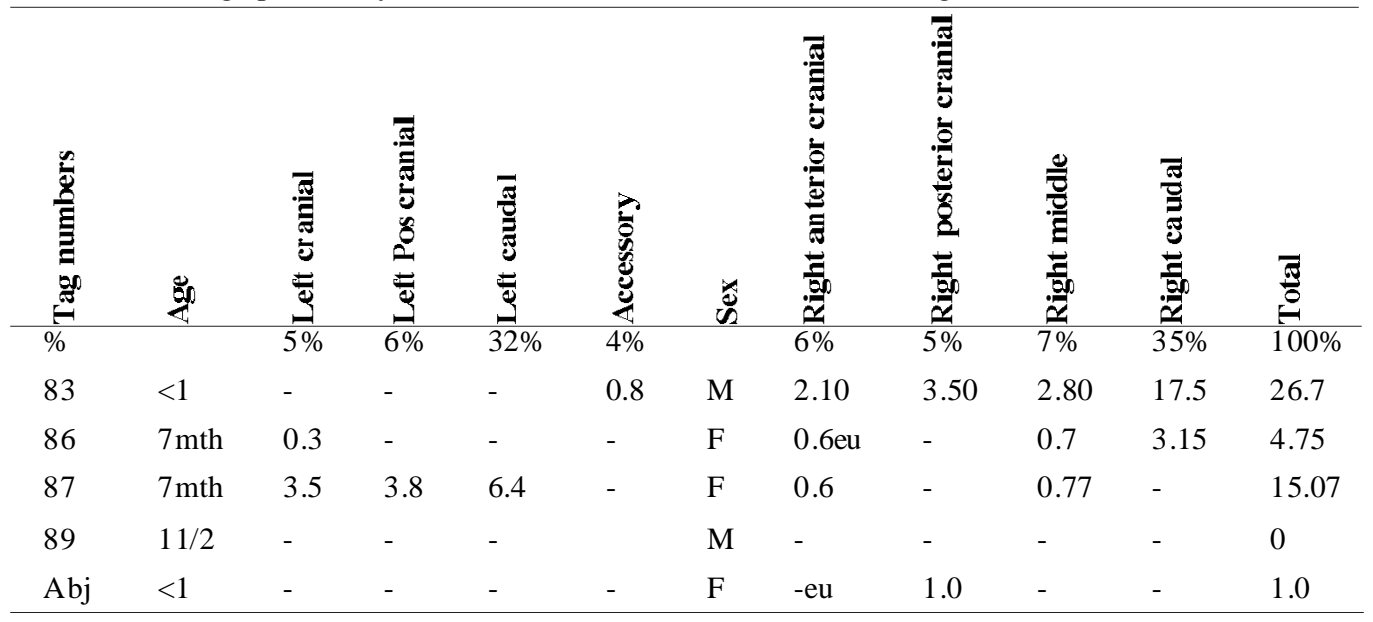

Table II. The distribution of the lung consolidation as regards the side of the lung.

\begin{tabular}{cccc}
\hline TAG n & Left Lung & Right Lung & Accessory \\
\hline 83 & 0 & 25.9 & 0.8 \\
86 & 0.3 & 4.45 & 0 \\
87 & 13.7 & 1.37 & 0 \\
89 & 0 & 0 & 0 \\
Abj & 0 & 1.0 & 0 \\
Mean \pm SEM & $2.8 \pm 2.71$ & $6.54 \pm 4.86$ & $0.16 \pm 0.16$ \\
\hline
\end{tabular}

Table III. Lobar Distribution of lung consolidation in natural PPR.

\begin{tabular}{lccc}
\hline TAG n & Cranial Lobe & Middle Lobe & Caudal Lobe \\
\hline 83 & 5.6. & 2.80 & 17.5 \\
86 & 0.9 & 0.7 & 3.15 \\
87 & 7.9 & 0.77 & 6.4 \\
89 & 0 & 0 & 0 \\
Abj & 1.0 & 0 & 0 \\
Mean \pm SEM & $3.08 \pm 1.54$ & $0.85 \pm 0.51$ & $5.41 \pm 3.23$ \\
\hline
\end{tabular}

Table IV. Age Influence on lung consolidation in natural PPR.

\begin{tabular}{lccc}
\hline TAG n & 7 Months & $<$ 1 Year & $\mathbf{1}_{-}$Years \\
\hline 83 & 0 & 26.7 & 0 \\
86 & 4.75 & 0 & 0 \\
87 & 15.07 & 0 & 0 \\
89 & 0 & 0 & 0 \\
Abj & 0 & 1.0 & 0 \\
MEAN \pm SEM & $3.96 \pm 2.91$ & $5.54 \pm 5.26$ & $0 \pm 0$ \\
\hline
\end{tabular}

Table V. Sex influence on pulmonary consolidation.

\begin{tabular}{lc}
\hline Sex & \% of consolidation \\
\hline Male & 13.04 \\
Female & 6.94 \\
\hline
\end{tabular}


Table VI. Villi length, villi width and cryptal depth mean percentage value.

\begin{tabular}{lccc}
\hline Group & Villi Length & Villi Width & Cryptal Depth \\
\hline PPR & $22.52 \pm 0.77$ & $7.70 \pm 0.65$ & $11.36 \pm 1.70^{*}$ \\
PPR+MH & $29.98 \pm 0.78$ & $7.23 \pm 0.53^{*}$ & $12.63 \pm 1.14^{*}$ \\
Control & $22.2 \pm 0.12$ & $9 \pm 0$ & \pm 0.08 \\
\hline
\end{tabular}

Values are presented as mean \pm SEM, PPR $(n=7), P P R+M H(n=8)$ \& Control $(n=5)$.

*Significant compared to animals in control group $\mathrm{p}<0.05$.

\section{DISCUSSION}

This investigation further highlights the lung and intestinal morphometry associated with natural and experimental PPR since the detailed pathological changes associated with natural PPR virus (Kumar et al., 2004) and experimental PPR virus (Emikpe \& Akpavie, 2011) and their combination with Mannheimia hemolytica (MH) has been previously reported (Emikpe et al.) especially the pattern of distribution pneumonia associated in goat (Emikpe \& Akpavie, 2010a).

This investigation evaluated the lung morphometry in goats that had natural PPR and it reveals that $60 \%$ of the goats examined had complicated PPR with pulmonary consolidation ranging between $4.75 \%$ and $26.7 \%$ while only $40 \%$ of the goats had uncomplicated PPR with pulmonary consolidation ranging between $0 \%$ and $1 \%$ which were similar to those previously described in experimental cases (Emikpe \& Akpavie, 2010a, 2011). This study also revealed that in natural PPR, the right lung was more affected than the left with $6.5 \%$ consolidation while the left had a mean value of $2.8 \%$. This is also similar to the report in experimental PPR (Emikpe \& Akpavie, 2010a). The distribution of the pulmonary consolidations was more to the caudal lobe with a mean value of $5.41 \%$ than the cranial lobe which has a mean value $3.08 \%$. This pattern that favoured the caudal lobe than the cranial further buttress the fact that most natural PPR are complicated with bacteria which has been reported to have extension of consolidation from cranial lobes to the middle and caudal lobes (Isoun \& Mann, 1972; Emikpe \& Akpavie, 2010a).

This study also showed the age influence on the pattern of pulmonary consolidation in PPR as higher consolidation were often observed in goats less than 1 year (Obi et al., 1983; Obi, 1984) while no noticeable pulmonary consolidation was observed in goat of $11 / 2$ years old. This age influence had been previously reported serologically in village and urban goats (Emikpe \& Akpavie, 2010b). That the male goats have higher pulmonary consolidation than the female goats as observed in this investigation further substantiates the report that serologically, more significant PPRV antibody were observed in bucks than does (Emikpe \& Akpavie, 2010b).

From this study, it showed that most natural PPR were complicated with bacteria and this secondary complication had been reported to hasten or contribute to the fatality associated with PPR especially those caused by lineage 1 viruses (Emikpe et al.). It also showed that pneumonia is one of the leading causes of the mortality in small ruminants (Ikede, 1977, 1978).

The pathological changes observed in the intestine include villous atrophy, degeneration and erosion with necrosis of the submucosa glands. There were also infiltrations of macrophages, giant cells, numerous lymphocytes in the submucosa with depletion of the payer's patches. The lesions were as previously reported in PPR (Obi et al., 1983; Emikpe \& Akpavie, 2011).

This investigation may be a first report describing the intestinal morphometric changes in PPR viral infected goats. From this study, there were significant differences in the mean length of the villi and the cryptal depth in PPR+MH infected goats. This may account for the projectile diarrhea usually reported in field PPR cases. Compared to the uncomplicated PPR, the cryptal depth alone was affected, this may account for the lower degree of diarrhea observed in the experimental case (Emikpe \& Akpavie, 2011). The reduction in the length of both unaffected and affected villi further confirms the report of Eligulashvili et al. (1997) that PPR virus affects the villi length and it results in lymphocytic cryptitis. This showed that once the infected villi, submucosa and the payer's patches were treated promptly in the absence of bacteria complication, the diarrhea can be controlled. This study also showed that secondary bacterial involvement in course of PPR caused by lineage 1 virus may also affect the gut morphometry and that could account for the severity of intestinal lesion commonly observed with field PPR in Nigerian goats.

In conclusion, this experiment showed that complicated PPR has a higher pulmonary consolidation and significant effect on the gut morphometry in goats.

\section{ACKNOWLEDGMENTS}

The effort of the staff of the histopathology unit of Department of Veterinary Pathology, University of Ibadan especially I.C Mpama, Ambrose Nwagbara and Augustine Joseph are appreciated. 
EMIKPE, B. O.; TAIWO, V. O. \& ONILUDE, O. M. Morfometría intestinal y pulmonar en la infección natural y experimental de la variante del virus Peste des petits ruminants del linaje 1 en cabras de Nigeria. Int. J. Morphol., 29(2):585-590, 2011.

RESUMEN: La morfometría del pulmón y el intestino en la infección del virus Peste des petits ruminants (PRR) de forma natural así como experimental es escaza en la literatura, de ahí la necesidad de este estudio. Fueron incluidas en este estudio las cabras que fueron sometidas a autopsia en el Departamento de Patología Veterinaria de la Universidad de Ibadan entre 2009 y 2010, con diagnóstico patológico macroscópico de PPR. El grado de neumonía como porcentaje del volumen pulmonar total fue estimado mediante los métodos estándar. También fue determinada la morfometría del intestino de las cabras infectadas experimentalmente con el virus PPR. Se utilizó la prueba "T" de Student para determinar la significancia en la evaluación de los efectos de edad, sexo, patrón de consolidación pulmonar en PPR natural y análisis de la morfometría intestinal. La PPR complicada tuvo una consolidación pulmonar altamente significativa en comparación con la PPR no complicada ( $\mathrm{p}<0,05)$. La consolidación pulmonar fue significativamente mayor en el pulmón derecho, con un valor porcentaje promedio de 6,54 en comparación al pulmón izquierdo (p <0,05). El lóbulo caudal fue más consolidado que los lóbulos craneal y medio en presencia del PPR natural. La consolidación pulmonar fue más frecuente en caprinos menores de un año, mientras que los machos cabríos tuvieron una consolidación pulmonar significativamente más alta (p <0,05). No hubo diferencias significativas en la longitud y ancho promedio de las vellosidades en cabras infectadas con PPR en comparación con el control, pero se observó una diferencia significativa en la profundidad de las criptas ( $\mathrm{p}<0,05)$. Hubo diferencia significativa en la longitud de las vellosidades y la profundidad media de las criptas en las cabras infectadas con PPR complicada (Mannheimia haemolytica) ( $\mathrm{p}<0,05)$ en relación al control. A partir de este estudio, se demostró que las infecciones con PPR natural se complicaron con bacterias, y estas complicaciones pueden haber contribuido a la mortalidad asociada el PPR, especialmente las causadas por el virus del linaje 1. Este estudio también mostró que la participación bacteriana secundaria en el curso de la PPR afecta la morfometría intestinal y que podría dar cuenta de la gravedad de la lesión intestinal observada comúnmente en la infección de PPR en cabras de Nigeria.

PALABRAS CLAVE: Morfometría; Intestino; Pneumonía; PPRV natural; PPRV experimental; Cabras.

\section{REFERENCES}

Eligulashvili, R.; Perl, S.; Stram, Y.; Friedgut, O.; Sheichat, N.; Samina, I. \& Trainin, Z. Immunohistochemical detection of peste des petits ruminants viral antigen in formalin-fixed, paraffin-embedded tissues from cases of naturally occurring infection. J. Vet. Diagn. Invest., 11(3):286-8, 1999.

Emikpe, B. O.; Sabri, Y. M.; Akpavie, S. O. \& Zamri-Saad, M. Experimental infection of Peste des petits ruminants virus and Mannheimia haemolytica A2 in goats: Immuno-localisation of Mannheimia haemolytica antigens. Vet. Res. Commun., 34(7):569-78, 2010.

Emikpe, B. O. \& Akpavie, S. O. The pattern of distribution of pneumonia in experimental Peste des petits ruminants Virus and/or Mannheimia hemolytica infection in goats. Int. J. Morphol., 28(2):563-8, 2010a.

Emikpe, B. O \& Akpavie S. O. The prevalence of Peste des petits ruminants virus antibodies in goats from selected rural and urban communities in Ibadan Nigeria. Bull. Anim. Health Prod. Afr., 58(2):147-53, 2010 b.

Emikpe, B. O. \& Akpavie, S. O. The clinicopathologic effects of Peste des petits ruminants virus in experimentally infected West African dwarf goats. Small Rum. Res., 95(2-3):168-73, 2011.
Eyarefe, O. D.; Emikpe, B. O. \& Arowolo, F. O. Small bowel responses to enteral honey and glutamine administration following massive small bowel resection in rabbit. Afr. J. Med. Med. Sci., 37(4):309-14, 2008.

Ikede, B. O. The pattern of respiratory lesions in goats and sheep in Nigeria, Part I--lesions in goats. Bull. Anim. Health Prod. Afr., 25(1):49-59, 1977.

Ikede, B.O. The pattern of respiratory lesions of goats and sheep in Nigeria, Part II--lesions in sheep. Bull. Anim. Health Prod. Afr., 26(2):172-85, 1978.

ILCA, International Livestock Centre for Africa. Small ruminant production in the humid tropics. Systems study No. 3. Addis Ababa, ILCA, 1979.

Isoun, T. T. \& Mann, E. D. Stomatitis and pneumoenteritis complex of sheep in Nigeria. Bull. Epizoot. Dis. Afr., 20:21-30, 1972.

Jericho, K. W. \& Langford, E. V. Aerosol vaccination of calves with Pasteurella haemolytica against experimental respiratory disease. Can. J. Comp. Med., 46(3):28792, 1982.

Kumar, P.; Tripathi, B. N.; Sharma, A. K.; Kumar, R.; 
EMIKPE, B. O.; TAIWO, V. O. \& ONILUDE, O. M. The gut and lung morphometry in experimental and natural lineage 1 variant of Peste des petits ruminants virus infection in Nigerian goats. Int. J. Morphol., 29(2):585-590, 2011.

Sreenivasa, B. P.; Singh, R. P.; Dhar, P. \& Bandyopadhyay, S. K. Pathological and immunohistochemical study of experimental Pestes des petits ruminants virus infection in goats. J. Vet. Med. B Infect. Dis. Vet. Public Health, 51(4):153-9, 2004.

Lamorde, A. G. Welcome address, proceedings of the 1st International Workshop on PPR. September, Ibadan, 1980. pp.1-2.

Nduaka, O. \& Ihemelandu, E. C. Observation on pneumonia enteritis complex in Dwarf goats in Eastern States of Nigeria - preliminary report. Bull. Epizoot. Dis. Afr., 21:87-98, 1973.

Obi, T. U. Clinical and epidemiological studies on PPR in sheep and goats in Southern Nigeria. PhD thesis, University of Ibadan, 1984.

Obi, T. U.; Ojo, M. O.; Durojaiye, O. A.; Kasali, O. B.; Akpavie, S. O. \& Opasina, B. A. PPR in goat in Nigeria: Clinical, microbiological and pathological features. Zentralbl. Veterinarmed. B., 30(10):751-61, 1983.

Odugbo, M. O.; Odama, L. E.; Umoh, J. U. \& Lombin, L. $\mathrm{H}$. The comparative pathogenicity of strains of eight serovars and untypeable strains of Mannheimia hemolytica in experimental pneumonia of sheep. Vet. Res., 35(6):661-9, 2004.

Osuagwuh, A. A. \& Akpokodje, C. West African Dwarf (Fouta Djallon) Goat 1. Causes of early mortality. Int. Goat and Sheep Res., 1:303-9, 1981.

Williamson, G. \& Payne, W. J. A. An introduction to animal husbandry in the tropics. $3^{\text {rd }}$ Edn. London, ELBS, 1984.
Correspondence to:

Benjamin Obukowho Emikpe, PhD

Department of Veterinary Pathology

University of Ibadan

Ibadan

NIGERIA

Phone: + 234-8066486080

Fax:+ 234-28103043

Email: banabis2001@yahoo.com benabis2001@gmail.com

Received: 27-10-2010

Accepted: 27-01-2011 